\title{
Communicative-Function-Based Sentence Classification for Construction of an Academic Formulaic Expression Database
}

\author{
Kenichi Iwatsuki ${ }^{1}$ \\ ${ }^{1}$ The University of Tokyo \\ iwatsuki@nii.ac.jp
}

\author{
Akiko Aizawa ${ }^{21}$ \\ ${ }^{2}$ National Institute of Informatics \\ aizawa@nii.ac.jp
}

\begin{abstract}
Formulaic expressions (FEs), such as 'in this paper, we propose' are frequently used in scientific papers. FEs convey a communicative function $(\mathrm{CF})$, i.e. 'showing the aim of the paper' in the above-mentioned example. Although CF-labelled FEs are helpful in assisting academic writing, the construction of FE databases requires manual labour for assigning CF labels. In this study, we considered a fully automated construction of a CF-labelled FE database using the top-down approach, in which the CF labels are first assigned to sentences, and then the FEs are extracted. For the CF-label assignment, we created a CF-labelled sentence dataset, on which we trained a SciBERT classifier. We show that the classifier and dataset can be used to construct FE databases of disciplines that are different from the training data. The accuracy of in-disciplinary classification was more than $80 \%$, while crossdisciplinary classification also worked well. We also propose an FE extraction method, which was applied to the CF-labelled sentences. Finally, we constructed and published a new, large CF-labelled FE database. The evaluation of the final CF-labelled FE database showed that approximately $65 \%$ of the FEs are correct and useful, which is sufficiently high considering practical use.
\end{abstract}

\section{Introduction}

Formulaic expressions (FEs), such as 'in this paper we propose', are a type of multi-word expressions and are repeatedly used in scientific papers. Some FEs convey a communicative function (CF) of a sentence, which represents intentions of authors. For example, 'in this paper, we propose' conveys the CF of 'showing the aim of the paper'.

Databases comprising CF-labelled FEs are required from a pedagogical perspective (Martinez and Schmitt, 2012), and a computer-based aca-

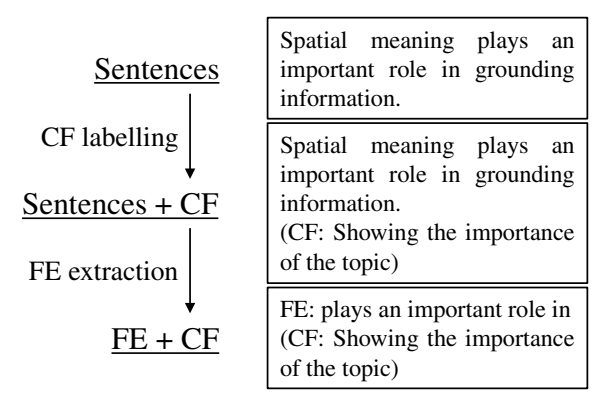

Figure 1: Process of creating FE database.

demic writing assistance system ${ }^{1}$ that uses such CF-labelled FEs has been proposed (Mizumoto et al., 2017). Several attempts have been made to extract FEs from scientific corpora and categorise them based on CFs (Cortes, 2013; Ädel, 2014; Mizumoto et al., 2017; Morley, n. d.; SimpsonVlach and Ellis, 2010; Lu et al., 2018). A CFlabelled FE database can be constructed using two main approaches: top-down and bottom-up approaches (Biber et al., 2007; Durrant and MathewsAydınl, 2011). By using the top-down approach, sentences are first assigned CF labels, and then FEs are extracted, while in the case of the bottomup approach, FEs are first extracted and then assigned CF labels. To date, both the approaches have been adopted because $\mathrm{CF}$ assignment is performed manually (Table 1). In this paper, we propose a fully automated construction of the CF-labelled FE database, where we consider the top-down approach to be more beneficial (Figure 1). This is because the bottom-up approach requires FEs to be classified, which is difficult because a perfect FE-extraction technique is yet to be realised, and FE embeddings have not been investigated intensively. The top-down approach requires sentence classification, which has highly improved with the recent advancements on pre-trained models.

\footnotetext{
${ }^{1}$ http://langtest.jp/awsum/
} 


\begin{tabular}{l|ccc|crrr}
\hline & \multicolumn{3}{|c|}{ Method for creating DB } & \multicolumn{4}{c}{ DB statistics } \\
& Approach & CF & FE & Discipl. & \#CFs & \#Docs & \#FEs \\
\hline Simpson-Vlach and El- & bottom-up & manual & corpus & mixed & 15 & - & 200 \\
lis (2010) & & & & & & & \\
Morley (n. d.) & - & manual & manual & mixed & 146 & 100 & $\simeq 2,000$ \\
Mizumoto et al. (2017) & top-down & manual & corpus & specific & 52 & 1,000 & - \\
Lu et al. (2018) & bottom-up & manual & corpus & mixed & 12 & 600 & 454 \\
\hline Ours & top-down & automated & sentence & specific & 32 & 61,728 & 86,931 \\
\hline
\end{tabular}

Table 1: Properties of the existing and proposed methods for the construction of CF-labelled FE databases and the statistics of the databases. The approach of Morley (n. d.) is unknown. For the CF assignment (CF), we adopted supervised machine-learning. The FE extraction (FE) was conducted manually using a corpus- or sentence-level method. Either FEs specific to one discipline were extracted or FEs used in a corpus in which several disciplines were mixed were extracted. The number of documents used for extraction and the extracted FEs of the existing and presented database were shown. Some studies did not disclose the number of documents or FEs. Morley (n. d.) constantly revises the database, and therefore the number of FEs is not fixed.

For CF-based sentence classification, we created a dataset for supervised learning. The dataset consists of a small number of sentences that were assigned CF labels. We collected the sentences from scientific papers of multiple disciplines. By using this dataset, we fine-tuned SciBERT (Beltagy et al., 2019). Additionally, because there are preferences for $\mathrm{CF}$ usage depending on disciplines and as the preparation and coverage of all CFs of every discipline are difficult, sentences to which any prepared $\mathrm{CF}$ label should not be assigned may appear in a corpus (no-CF sentences). These no$\mathrm{CF}$ sentences will have a negative effect on the classification performance. Based on the recent work on out-of-distribution detection in natural language processing (Hendrycks and Gimpel, 2017; Hendrycks et al., 2020), we used the maximum value of the softmax layer as the threshold to filter no-CF sentences in order to improve the final precision. The experimental results show that the maximum value of the softmax layer works well as the threshold to filter out undesirable sentences.

We carefully considered multidisciplinary problems in the classification. Although the development of a training dataset for every discipline in the world is obviously impossible, demonstrating a successful classification using a single disciplinary dataset is not sufficient for practical use. In this study, we determined whether a model trained on a corpus of one discipline can be applied to that of another discipline. Moreover, the effects of a pre-training dataset were examined by comparing SciBERT and BERT (Devlin et al., 2019). The experimental results show that the classifiers performed fairly well in terms of both in-discipline and cross-discipline data, and the performance was only slightly affected when scientific papers were not used as pre-training data.

For the FE-extraction process, one FE should be extracted from one sentence because CF labels are assigned to each sentence; this is termed as sentence-level approach (see Section 2.2). Therefore, we propose a sentence-level FE extraction method that is based on an existing method (Iwatsuki et al., 2020b). The method consists of three steps: named and scientific entity removal, dependency-structure-based word removal, and word-association-measure-based word removal.

Finally, we created a new, large, multidisciplinary CF-labelled FE database and evaluated it by asking human evaluators whether each instance was assigned a correct CF label and whether an FE was useful for writing a paper. The results show that approximately $65 \%$ of the collected FEs are appropriate.

The contributions of our study are as follows:

- we created and published the CF-labelled sentence dataset, which is the first dataset for training and evaluation of CF-based classification;

- we showed that a simple SciBERT-based neural classifier performed reasonably well for the CF labelling problem;

- we showed that the SciBERT classifier can be used even though the discipline of the training data is different from the inferred one;

- we proposed an FE extraction method; and 
- we constructed a CF-labelled FE database with the top-down approach, which is larger than the existing databases but still maintains high quality.

\section{Related Work}

\subsection{CFs in Scientific Papers}

The CFs of scientific papers were first introduced by Swales (1990), who focused on the CFs in the introduction section. The author proposed a hierarchical structure of CFs, in which move was considered a larger unit of $\mathrm{CF}$ and step was a smaller unit belonging to move. He found that the introduction section consists of three moves: 'establishing a territory', 'establishing a niche', and 'occupying the niche'. Each move has several steps, such as 'claiming centrality' and 'presenting research questions or hypotheses' (Swales, 2004). Following his work, a host of studies extended the concept to all parts of a scientific paper. Most studies focused on very limited part of scientific papers; only the introduction (Ozturk, 2007), methods (Lim, 2006; Cotos et al., 2017), results (Basturkmen, 2009; Lim, 2010), discussion sections (Peacock, 2002; Basturkmen, 2012), or the abstracts (Lorés, 2004; Darabad, 2016; Rashidi and Meihami, 2018; Saboori and Hashemi, 2013).

The concept was extended to all parts of a scientific paper. For example, Kanoksilapatham (2005) proposed the $\mathrm{CF}$ structure of all the sections in biochemistry papers. Cotos et al. (2015) proposed a $\mathrm{CF}$ set for all four sections, i.e. introduction, methods, results, and discussion sections. Maswana et al. (2015) compared the usage of the CFs in five engineering fields and found that certain CFs are preferred depending on the discipline.

Argumentative Zoning is a similar concept based on the rhetorical moves (Teufel, 1999). It had seven categories, which were later extended to 15 categories by Teufel et al. (2009)

Previous studies on CF-based classification used conditional random fields (Hirohata et al., 2008), a classifier chain with sequential minimum optimisation, Rakel with the J48 algorithm (Dayrell et al., 2012), a Bayes classifier, and a decision tree (Soonklang, 2016). However, these studies only focused on abstracts of scientific papers. Therefore, existing CF-labelled FE lists were created by manually assigning CF labels (Table 1), complicating the construction of a large CF-labelled FE database. Recently, Fiacco et al. (2019) used a hierarchical
Bi-LSTM+CRF to classify sentences. However, CF-labelled sentence corpora are yet to be made available to the public.

\subsection{FE-Extraction Methods}

Two approaches are used for extracting FEs: corpus- and sentence-level approaches. Based on the intuition that FEs appear frequently or words composing FE are strongly associated, most studies use the corpus-level approach, in which statistical metrics, such as frequency or mutual information, are applied to a whole corpus. To extract FEs, word $n$-grams were collected from a whole corpus by using the metrics (Biber et al., 2004; SimpsonVlach and Ellis, 2010; Kermes, 2012; Mizumoto et al., 2017). However, this approach results in the extraction of an explosive number of overlapping $n$-grams, thus causing a serious problem in the CFlabelled FE database construction. For instance, suppose 'in this paper we propose', 'this paper we propose a', and 'in this paper we propose a new method' are extracted, a criterion is needed to determine which of these are regarded as FEs; however, determining such a criterion is difficult.

The $n$-gram lattice method (Brooke et al., 2017) is one approach to address this problem; here, scores of various aspects of formulaicity are first calculated for all word $n$-grams. Next, an objective function that contains all scores of the $n$-grams is maximised to determine which $n$-grams should be disregarded and which should remain. However, this method is still not focused on FEs conveying CFs but on general phrasal expressions; thus, it is thus not suitable for our setting.

The sentence-level approach assumes that one FE occurs in one sentence. Thus, 'in this paper we propose a new method' can be extracted, but 'this paper we propose a' cannot be extracted from a sentence. This approach is also useful for extracting FEs with a slot (Vincent, 2013), into which some words can be inserted, such as 'however, * have not been reported'. This setting is regarded as a sequence-labelling problem, in which each word of a sentence is labelled as either formulaic or non-formulaic. Liu et al. (2016) proposed removing topic-specific words as non-formulaic words, using latent Dirichlet allocation. They used a corpus consisting of papers from various disciplines, and tried to remove discipline-specific vocabulary. Thus, this is not suitable for extracting disciplinespecific FEs. Iwatsuki et al. (2020b) proposed re- 
moving scientific and named entities in addition to dependency-based word removal.

The evaluation of the FE extraction model is another problem. Brooke et al. (2015) pointed out that the comparison of newly extracted FEs with existing reference is unreasonable because if a reference is on point, a new lexicon need not be created. Thus, Iwatsuki et al. (2020b) proposed evaluating FE extraction methods by a CF-based sentence retrieval task as an extrinsic task based on the idea that FEs convey a CF of a sentence.

\subsection{CF-Labelled FE Databases}

Table 1 describes the existing CF-labelled FE databases. Previous studies have shown that FEs are discipline-specific, and the resource of academic vocabulary should be presented for each discipline (Hyland and Tse, 2007; Liu, 2012). Thus, the development of CF-labelled FE databases for each discipline is important; however, many studies have focused on general FEs, which were extracted from a mixed corpus consisting of scientific papers on multiple disciplines. Some studies adopted the discipline-specific approach; Mizumoto et al. (2017) considered only the journals on applied linguistics, while Lu et al. (2018) used only the introductions of social-science papers. Moreover, only a small number of documents were used because the existing resources require manual labour for assigning CF labels.

Hence, we contend that the automated CF-based classification is helpful for constructing a large, comprehensive CF-labelled FE database. In this study, we developed a discipline-specific database based on large corpora of scientific papers from four disciplines.

\section{Methods}

\subsection{Corpora and Datasets}

\subsubsection{Corpora of Scientific Papers}

In this study, we considered the corpora which satisfy the following conditions. First, because we use full text of scientific papers and have made all the data public, papers must be open access. Second, to construct a comprehensive database, the corpora size is important. Third, for cross-discipline analyses, a discipline-specific journal is preferred to a multidisciplinary journal. We selected a corpus containing at least 10,000 papers.

Under these three conditions and based on the diversity of the disciplines, we selected four corpora:
ACL Anthology Sentence Corpus ${ }^{2}$ for computational linguistics (CL), Molecules ${ }^{3}$ for chemistry (Chem), Oncotarget ${ }^{4}$ for oncology (Onc), and Frontiers in Psychology ${ }^{5}$ for psychology (Psy). Each corpus comprises more than 10,000 papers and is open access to full text (creative commons licence).

For pre-processing, we performed sentence splitting using ScispaCy (Neumann et al., 2019) and replaced citations and mathematical formulae with a special token. By using a simple rule-based method, section labels were normalised into five classes: introduction, methods, results, discussion, and other. Each sentence was assigned a section label; we did not use sentences belonging to the 'other' class. The numbers of sentences and documents are listed in Table 2.

\begin{tabular}{lrrr}
\hline Corpus & \#Doc. & \#Sent. & \#Words \\
\hline CL & 13,921 & $1,612,921$ & $32,698,072$ \\
Chem & 15,949 & $1,703,902$ & $39,303,460$ \\
Onc & 19,541 & $3,029,285$ & $68,719,634$ \\
Psy & 12,317 & $1,948,082$ & $49,329,526$ \\
\hline
\end{tabular}

Table 2: Number of documents (doc), sentences (sent), and words in each corpus.

\subsubsection{CF Set and CoreFEs}

Till date, there is no established CF set, and some $\mathrm{CFs}$ are not used or are frequently used in a specific discipline. Proposing a new $\mathrm{CF}$ set is beyond the scope of this study; however, we must select a CF set. We adopted the CF set proposed by Iwatsuki et al. (2020a), which was based on CFs used in Academic Phrasebank (Morley, n. d.). Table 3 describes the numbers of CFs in each section. (All the CFs are listed in Table 13 in the appendix.) CoreFE is an FE that is shortened so that it can be used as a query for sentence retrieval (Generally, longer phrases result in few or no results in sentence retrieval). We used CoreFEs to create the CF-labelled sentence dataset.

\subsubsection{CF-Labelled Sentence Dataset}

For the CF-based classification, we created a sentence dataset by using the aforementioned corpora. To effectively collect labelled sentences, we used the following procedures. First, the CoreFEs were

\footnotetext{
${ }^{2}$ https://github.com/KMCS-NII/AASC

${ }^{3}$ https://www.mdpi.com/journal/ molecules

${ }^{4}$ https: / / www. oncotarget. com/

${ }^{5}$ https: //www. frontiersin.org/journals/ psychology
} 


\begin{tabular}{l|r}
\hline Section & \#CFs \\
\hline Introduction & 11 \\
Methods & 6 \\
Results & 6 \\
Discussion & 9
\end{tabular}

Table 3: Numbers of CFs for each section.

used as queries to retrieve sentences from the corpora. Although the CoreFEs have CF labels, the retrieved sentences may not always have the same CFs.

Next, we used Amazon Mechanical Turk (AMT) to check if each sentence was assigned correct labels; this process was three-fold. First, a correct set of sentences was prepared. Two experts were asked whether the sentences in the correct set were correctly labelled, and the sentences whose labels were judged incorrect by at least one expert were removed. Another set of sentences, called the incorrect set, was prepared, in which the same sentences were randomly assigned incorrect labels. Second, by using these sets, a pilot test was conducted on AMT. Five annotators were recruited and asked to check whether the labels were correct or not. Based on this pilot test, we determined the threshold to cut off sentences. Finally, a larger set of sentences was prepared, which was different from the set used in the pilot test. Another five annotators were asked to perform the same task on the set. The final dataset comprises the sentences satisfying the threshold.

\subsection{Sentence Classification}

\subsubsection{Classifier}

We assigned each sentence a CF label, and this task can be regarded as a CF-based sentenceclassification problem. In addition, we used SciBERT (Beltagy et al., 2019) with an additional linear layer for classification. We split the CFlabelled sentence dataset into training/development and evaluation sets so that four sentences for each $\mathrm{CF}$ were in the evaluation set. Then, we conducted five-fold cross validation using the training/development set for parameter tuning. Subsequently, we fine-tuned the classifier and evaluated the classification accuracy.

Because CF sets in scientific papers have not been established, the CF set we used cannot satisfactorily cover all sentences written in papers. Additionally, pre-processing errors, such as sentence splitting, sometimes result in no-CF sen- tences. Thus, in some scenarios, no CF should be assigned to a sentence and no-CF sentences must be removed. The no-CF class is not contained in the training dataset; this problem is regarded as the out-of-distribution detection problem. Although the maximum value of the softmax layer is not a perfect metrics for out-of-distribution detection, pre-trained transformers, such as BERT and RoBERTa, with a softmax layer are good detectors of out-of-distribution data (Hendrycks and Gimpel, 2017; Hendrycks et al., 2020).

To manage the no-CF sentences, we used the maximum softmax value of the classifier, and verified its performance. The verification was performed in the same manner as the creation of the CF-labelled sentence dataset. That is, we asked five AMT annotators whether the output label was correct. The threshold was also the same: 5/5.

\subsubsection{Multidisciplinary Perspectives}

To create a multidisciplinary database, the classification must be applied to various disciplinary texts. As it is costly to create a training dataset manually for each discipline, we tested whether the classifier trained on a dataset of one discipline can be immediately applied to the datasets of other disciplines.

SciBERT was trained on scientific papers from Semantic Scholar ${ }^{6}$ (Beltagy et al., 2019). The corpora used in this study are open access and were also included in Semantic Scholar. Thus, we hypothesise that the cross-disciplinary adaptation is successful because the sentences are (partly) contained in the pre-training dataset. Therefore, the method cannot be applied to disciplines that are not covered by the pre-training dataset. To verify this hypothesis, we compared SciBERT to BERT, which was pre-trained on the book corpus and Wikipedia and not on scientific papers (Devlin et al., 2019), for cross-discipline sentence classification.

\subsection{FE Extraction}

To extract FEs, we propose a method based on Iwatsuki et al. (2020b), which is a sentence-level method; one FE was extracted from one sentence. We applied this method, which comprises three steps, to the classified sentences.

In the first step, the named and scientific entities are removed from a sentence. The entity recognition was performed using SpERT (Eberts and

\footnotetext{
${ }^{6}$ https: // www. semanticscholar.org/
} 
Ulges, 2020), which sits atop the leader-board of NER tasks for scientific entities ${ }^{7}$. For training, we used CoNLL04 (Roth and Yih, 2004), a corpus labelled with general-purpose named entities, and SciERC (Luan et al., 2018), a corpus of scientific papers labelled with scientific entities. The CoNLL04 labels are location, organisation, people, and other; SciERC labels are task, method, evaluation metric, material, other scientific terms, and generic. By removing the named entities, a sentence was split into several spans.

In the second step, we used the dependency structure of a sentence analysed by Stanford CoreNLP (Qi et al., 2018). Words that were neither in the span containing a sentence's root nor organised by the root were then removed. The assumption here was that FEs representing CFs of sentences appeared in the structural centres in the sentence dependency structures (Iwatsuki et al., 2020b).

Steps 1 and 2 work well if several named entities are contained in a sentence; otherwise, an almost full sentence is produced, which is too long to be an FE. Thus, we propose an additional filtering step that further removes non-relevant generic terms from the candidate FE spans. This is based on the assumption that each word of an FE is strongly associated with each other. Thus, the association between fragments of an FE should be strong. For instance, 'in this paper we' and 'propose' are strongly associated, while 'in this paper we' and 'talk' are not.

On the basis of this observation, we first extracted all pairs of an $n$-gram and its neighbour word from each candidate span obtained after Step 2. For example, pairs such as ('in this', 'paper') or ('paper we', 'propose') are obtained when $n=2$. Next, for each pair, we calculated the association measures between an $n$-gram and a neighbour word. We used the local mutual information (LMI), which is formalised as follows:

$$
\operatorname{LMI}(a, b)=f(a, b) \cdot \log \frac{p(a, b)}{p(a) p(b)},
$$

where $a$ and $b$ denote a word, $a, b$ denotes the cooccurrence of the words, $p(a)$ is a probability of occurrence of $a$, and $f(a)$ is a frequency of $a$ in a corpus (Evert, 2005). Finally, the pairs with the top $k$ scores were labelled as an FE. To avoid generating FEs that are too short, this third process was

\footnotetext{
${ }^{7}$ https: / / paperswithcode.com/sota/ named-entity-recognition-ner-on-scierc
}

CF: Suggestion of future work

Sentence:

In the future, we plan to explore how to combine more features such as part-of-speech tags into our model.

Figure 2: Example of the database evaluation. An FE is underlined in the sentence, which has been retrieved from Cao et al. (2014).

applied only when the length of the resulting word sequence of Step 2 was more than $k$ words. From our preliminary experiments, we determined to use $(n, k)=(2,7)$.

Because FEs are assumed to be used as they are, we did not lemmatise them. Formulaicity sometimes does not allow the replacement of a word in an FE with another word or flection. For example, tenses can be section-specific (present or past): 'in this paper we proposed' rarely occurs in the introduction sections. Formulaicity also avoids grammatical errors such as 'little researches have been done'. Many previous studies did not lemmatise FEs (Simpson-Vlach and Ellis, 2010; Mizumoto et al., 2017; Pan et al., 2016; Esfandiari and Barbary, 2017).

\subsection{Constructing CF-Labelled FE Database}

We created the CF-labelled FE database using the following steps. Step 1: CF labels were assigned to each sentence in a corpus and no-CF sentences were removed. Step 2: FEs were extracted from each sentence. Step 3: Noisy FEs were filtered out. If an FE was assigned multiple CF labels, only one $\mathrm{CF}$ was selected by majority voting. If none of the CFs took the majority, the FE was removed. Any CF-labelled FE occurring less than three times was also removed.

We evaluated the final database from two perspectives: whether a sentence was assigned a correct label and whether an FE was useful for writing a scientific paper.

The evaluation was conducted on the AMT. A sentence and its CF label were shown to evaluators, and an FE was highlighted in the sentence (see Figure 2). The evaluators were asked whether the sentence conveyed the $\mathrm{CF}$ and whether the $\mathrm{FE}$ was useful. Each FE was annotated by five evaluators, and if it was not evaluated by all as correct or useful, it was regarded as incorrect or useless. 


\begin{tabular}{rrr}
\hline Threshold & Precision & Recall \\
\hline $5 / 5$ & 0.94 & 0.80 \\
$4 / 5$ & 0.79 & 0.98 \\
$3 / 5$ & 0.62 & 1.00 \\
$2 / 5$ & 0.54 & 1.00 \\
$1 / 5$ & 0.50 & 1.00 \\
\hline
\end{tabular}

Table 4: Threshold indicates the number of annotators (out of five) who judged pairs of the sentence and CF label as correct.

\begin{tabular}{lr}
\hline Discipline & \#Sentence \\
\hline CL & 612 \\
Chem & 644 \\
Onc & 600 \\
Psy & 687 \\
\hline
\end{tabular}

Table 5: Numbers of sentences in the final dataset.

\section{Results}

\subsection{CF-Labelled Sentence Dataset}

The correct and incorrect sets consist of 55 sentences. The results of the pilot test are shown in Table 4. Accordingly, we set the threshold to 5/5 because high precision was important for creating the FE database rather than recall, and the strictest threshold did not significantly reduce the sentences. Table 5 lists the total number of sentences.

\subsection{CF-Based Sentence Classification}

The classification results are shown in Table 6. SciBERT worked well, which implies that this BERT-based classifier has the ability to capture CFs of sentences.

We also verified with SciBERT whether the maximum value of the softmax layer can be used as the threshold to filter out no-CF sentences. We first classified all the sentences in the corpora, and then split the classified sentences into six categories based on the maximum softmax score: [0.00, 0.60], $(0.60,0.70],(0.70,0.80],(0.80,0.90],(0.90,0.99]$, $(0.99,1.00]$. Next, we randomly sampled 100 sentences from each range, and the sentences were evaluated by five annotators on AMT. The evaluation method was the same as that used for collecting the CF-labelled sentences. The accuracy of each range is shown in Table 7. For database construction, we removed the sentences with a score of 0.80 or lower.

\begin{tabular}{lccccc}
\hline Discipline & $\mathrm{I}$ & $\mathrm{M}$ & $\mathrm{R}$ & $\mathrm{D}$ & Avg. \\
\hline CL & 0.83 & 0.83 & 1.00 & 0.91 & 0.90 \\
Chem & 0.95 & 0.79 & 0.88 & 0.89 & 0.89 \\
Onc & 0.92 & 0.63 & 0.92 & 0.92 & 0.88 \\
Psy & 0.93 & 0.88 & 0.96 & 0.81 & 0.84 \\
\hline ALL & 0.97 & 0.92 & 0.98 & 0.94 & 0.95
\end{tabular}

Table 6: Accuracy scores of each section (Introduction, Methods, Results, Discussion) in each discipline. The average (Avg.) indicates the macro average.

\begin{tabular}{lrr}
\hline Range & Accuracy & Proportion \\
\hline$(0.99,1.00]$ & 0.69 & $76.1 \%$ \\
$(0.90,0.99]$ & 0.67 & $12.4 \%$ \\
$(0.80,0.90]$ & 0.74 & $3.7 \%$ \\
$(0.70,0.80]$ & 0.51 & $2.4 \%$ \\
$(0.60,0.70]$ & 0.51 & $2.1 \%$ \\
$(0.00,0.60]$ & 0.43 & $3.3 \%$ \\
\hline
\end{tabular}

Table 7: Accuracy scores of each range of the maximum value of the softmax layer, and the proportion of sentences in the corpora.

\subsection{Multidisciplinary Perspective}

We tested whether SciBERT trained on one discipline can be applied to different disciplines. The results are shown in Table 8.

We also tested the effects of the pre-trained dataset by comparing the results of SciBERT and BERT. Table 9 and 10 show the BERT results; compared with the results shown in Table 6 and 8, the two models did not show a considerable difference.

\subsection{Constructing CF-Labelled FE Database}

The CF-labelled FE database was evaluated by sampling 200 FEs. The results are shown in Table 11.

Incorrect sentence-CF pairs were obtained because the classifier made errors and some sentences were not a complete sentence. An example of an incomplete sentence is 'of three independent experiments.'; this was produced because of the error of sentence splitting. Examples of useful FEs are

\begin{tabular}{|c|c|c|c|c|c|}
\hline & \multicolumn{4}{|c|}{ Evaluation } \\
\hline & & CL & Chem & Onc & Psy \\
\hline \multirow{4}{*}{ 泃 } & CL & 0.90 & 0.88 & 0.86 & 0.84 \\
\hline & Chem & 0.84 & 0.89 & 0.91 & 0.84 \\
\hline & Onc & 0.75 & 0.89 & 0.88 & 0.82 \\
\hline & Psy & 0.88 & 0.89 & 0.88 & 0.84 \\
\hline
\end{tabular}

Table 8: Average accuracy scores. The training and evaluation datasets comprise different discipline. 


\begin{tabular}{lccccc}
\hline Discipline & $\mathrm{I}$ & $\mathrm{M}$ & $\mathrm{R}$ & $\mathrm{D}$ & Avg. \\
\hline CL & 0.90 & 0.84 & 0.96 & 0.93 & 0.88 \\
Chem & 0.93 & 0.87 & 0.93 & 0.93 & 0.89 \\
Onc & 0.92 & 0.66 & 0.94 & 0.95 & 0.86 \\
Psy & 0.92 & 0.88 & 0.95 & 0.89 & 0.92 \\
\hline
\end{tabular}

Table 9: Accuracy scores acquire by BERT classifier.

\begin{tabular}{|c|c|c|c|c|c|}
\hline & \multicolumn{4}{|c|}{ Evaluation } \\
\hline & & $\mathrm{CL}$ & Chem & Onc & Psy \\
\hline \multirow{4}{*}{ 冝 } & CL & 0.88 & 0.87 & 0.82 & 0.85 \\
\hline & Chem & 0.85 & 0.89 & 0.91 & 0.86 \\
\hline & Onc & 0.74 & 0.91 & 0.86 & 0.82 \\
\hline & Psy & 0.87 & 0.92 & 0.88 & 0.92 \\
\hline
\end{tabular}

Table 10: Average accuracy scores by BERT.

'plays a crucial role in' (CF: Showing the importance of the topic) and 'no significant differences were detected in' (CF: Description of the results), while 'et al demonstrated that' (CF: Showing background provided by past work) and 'is to use $a$ ' (CF: Showing brief introduction to the methodology) were judged useless.

The statistics of the database are shown in Table 2. To show discipline-specific FEs, we calculated odds ratio for each $\mathrm{CF}$ of each discipline. Table 12 illustrates the top 5 high odds ratio FEs in the 'description of the process' $\mathrm{CF}$ in the introduction section. These FEs are not considered rare, as some of them occur more than a thousand times in a corpus. The differences between disciplines are relative, and these results may change if another corpus of a different discipline is added; however, preference for FEs still exists across disciplines. This reinforces the previous claim that FEs are discipline-specific (Hyland and Tse, 2007; Hyland, 2008; Durrant, 2015; Jalilifar et al., 2016). All the discipline-specific FEs are listed in Table 15 in the appendix.

\begin{tabular}{|c|c|c|c|c|}
\hline & \multicolumn{2}{|l|}{ Sentence } & Total \\
\hline \multirow{3}{*}{ 壱 } & Useful & 130 & 12 & 142 \\
\hline & Useless & 34 & 24 & 58 \\
\hline & Total & 164 & 36 & 200 \\
\hline
\end{tabular}

Table 11: Results of the evaluation of the constructed CF-labelled FE dataset.

\begin{tabular}{|c|c|c|}
\hline \multicolumn{3}{|c|}{ Section: Methods } \\
\hline \multicolumn{2}{|c|}{ CF: Description of the process } & \# \\
\hline \multirow{5}{*}{$\mathrm{CL}$} & we assume that the & 19 \\
\hline & we calculate the & 17 \\
\hline & we also use & 15 \\
\hline & we then use the & 11 \\
\hline & are trained using & 10 \\
\hline \multirow{5}{*}{ Chem } & $\begin{array}{l}\text { was stirred at room tempera- } \\
\text { ture for }\end{array}$ & 104 \\
\hline & hrms mz m h calcd & 90 \\
\hline & were recorded on an & 89 \\
\hline & were purchased from & 642 \\
\hline & the mixture was stirred for & 74 \\
\hline \multirow{5}{*}{ Onc } & were purchased from & 2,972 \\
\hline & was used for & 1,129 \\
\hline & was purchased from & 2,129 \\
\hline & were maintained in & 527 \\
\hline & were used for & 548 \\
\hline \multirow{5}{*}{ Psy } & $\begin{array}{l}\text { study was carried out in ac- } \\
\text { cordance with the }\end{array}$ & 360 \\
\hline & $\begin{array}{l}\text { gave written informed con- } \\
\text { sent in accordance with the }\end{array}$ & 250 \\
\hline & was approved by the & 165 \\
\hline & $\begin{array}{l}\text { study was approved by the } \\
\text { ethics committee of }\end{array}$ & 156 \\
\hline & $\begin{array}{l}\text { gave written informed con- } \\
\text { sent in accordance with the } \\
\text { declaration of helsinki }\end{array}$ & 111 \\
\hline
\end{tabular}

Table 12: Examples of discipline-specific FEs. The complete list is provided in the appendix. All the FEs are lower-cased. The number of occurrences of each FE in the corpus is also shown.

\section{Discussion}

\subsection{CF-Based Sentence Classification}

The classification accuracy was quite high, and thus the results can be a good baseline for a CFbased sentence classification task. We published the dataset so that other researchers can tackle the classification task.

The no-CF detection worked fairly. From Table 7 it can be said that the maximum value is often too high; $30 \%$ of the CF labels assigned scores higher than 0.99 were incorrect. However, much lower $(\leq 0.80)$ scores tended to cause lower accuracy. Thus, this approach is useful to improve overall precision, which is more important to construct a FE-CF database than recall. 


\subsection{Problems in Multidisciplinary Data}

We raised two questions: Can the classifier trained on one discipline be applied to other disciplines? Does the pre-training data affect the classification performance?

The results of the sentence classification imply that the SciBERT classifier trained on a dataset of one discipline can be applied to datasets of other disciplines. This mitigates the labour of creating a training dataset for all other disciplines. Therefore, we argue that to create another FE-CF database of another discipline, the CF-labelled sentence dataset we created can be used as a training dataset.

The comparison of SciBERT (Table 6) and BERT (Table 9) denied our hypothesis that the cross-discipline adaptation worked as long as the discipline was included in pre-training data. Therefore, the ability of discipline adaptation does not come from the pre-training dataset, which implies that the classifier could be used irrespective of whether a discipline is covered by the pre-training dataset.

\subsection{Quality of the FE-CF Database}

The results of the evaluation (Table 11) imply that if five CF-labelled FEs are retrieved, approximately three (130/200) are good FEs. Considering scenarios where users search for FEs to write a scientific paper, the selection of one FE from five candidates containing two incorrect FEs can be considered realistic.

Consider another case in which users use an FE as a query to obtain some example sentences that play the role of a specific CF. In this case, the evaluation results imply that approximately $90 \%$ (130/142) of the retrieved sentences are satisfying results. In some cases, the same FEs appear in different $\mathrm{CF}$ categories. For example, 'play critical roles in' is used in 'Showing the importance of the topic (introduction)' and 'Showing background provided by past work (discussion)'. Thus, compared to the mere collection of FEs, the addition of CF labels to FEs is proved to be more helpful.

\section{Conclusion}

In this paper, we proposed the fully-automated construction of a CF-labelled FE database, by solving the problem of CF-based sentence classification. We carefully considered a practical case of creating a FE database of other disciplines. The experimental results showed that the proposed classifi- cation method and dataset can be utilised to construct FE databases for disciplines different from those that we used. We proposed the FE extraction method that utilised the named and scientific entity removal, dependency-structure-based word removal, and word-association-measure-based word removal. Combining the proposed methods, we finally constructed the new CF-labelled FE database. The CF-labelled sentence database and the CFlabelled FE database are available on our website ${ }^{8}$. We expect that the proposed database could be used by pedagogical practitioners and for computeraided academic-writing assistance such as sentence retrieval and automated proofreading.

\section{Acknowledgements}

This work was supported by JSPS KAKENHI Grant Numbers 19J12466 and 18H03297.

\section{References}

Annelie Ädel. 2014. Selecting quantitative data for qualitative analysis: A case study connecting a lexicogrammatical pattern to rhetorical moves. Journal of English for Academic Purposes, 16:68-80.

Helen Basturkmen. 2009. Commenting on results in published research articles and masters dissertations in language teaching. Journal of English for Academic Purposes, 8:241-251.

Helen Basturkmen. 2012. A genre-based investigation of discussion sections of research articles in dentistry and disciplinary variation. Journal of English for Academic Purposes, 11:134-144.

Iz Beltagy, Kyle Lo, and Arman Cohan. 2019. SciBERT: A pretrained language model for scientific text. In Proceedings of the 2019 Conference on Empirical Methods in Natural Language Processing and the 9th International Joint Conference on Natural Language Processing (EMNLP-IJCNLP), pages 36153620, Hong Kong, China. Association for Computational Linguistics.

Douglas Biber, Ulla Connor, and Thomas A. Upton. 2007. Discourse on the Move: Using Corpus Analysis to Describe Discourse Structures. John Benjamins Publishing.

Douglas Biber, Susan Conrad, and Viviana Cortes. 2004. If you look at ... : Lexical Bundles in University Teaching and Textbooks. Applied Linguistics, 25(3):371-405.

Julian Brooke, Adam Hammond, David Jacob, Vivian Tsang, Graeme Hirst, and Fraser Shein. 2015. Building a lexicon of formulaic language for language

\footnotetext{
${ }^{8}$ https://iwa2ki.com/FE/
} 
learners. In Proceedings of the 11th Workshop on Multiword Expressions, pages 96-104, Denver, Colorado, USA. Association for Computational Linguistics.

Julian Brooke, Jan Šnajder, and Timothy Baldwin. 2017. Unsupervised acquisition of comprehensive multiword lexicons using competition in an n-gram lattice. Transactions of the Association for Computational Linguistics, 5:455-470.

Ziqiang Cao, Sujian Li, and Heng Ji. 2014. Joint learning of Chinese words, terms and keywords. In Proceedings of the 2014 Conference on Empirical Methods in Natural Language Processing (EMNLP), pages 1774-1778, Doha, Qatar. Association for Computational Linguistics.

Viviana Cortes. 2013. The purpose of this study is to: Connecting lexical bundles and moves in research article introductions. Journal of English for Academic Purposes, 12(1):33-43.

Elena Cotos, Sarah Huffman, and Stephanie Link. 2015. Furthering and applying move/step constructs: Technology-driven marshalling of Swalesian genre theory for EAP pedagogy. Journal of English for Academic Purposes, 19:52-72.

Elena Cotos, Sarah Huffman, and Stephanie Link. 2017. A move/step model for methods sections: Demonstrating rigour and credibility. English for Specific Purposes, 46:90-106.

Ali Mohammadi Darabad. 2016. Move analysis of research article abstracts: A cross-disciplinary study. International Journal of Linguistics, 8(2):125-140.

Carmen Dayrell, Arnaldo Candido Jr., Gabriel Lima, Danilo Machado Jr., Ann Copestake, Valéria Feltrim, Stella Tagnin, and Sandra Aluisio. 2012. Rhetorical move detection in english abstracts: Multilabel sentence classifiers and their annotated corpora. In Proceedings of the Eighth International Conference on Language Resources and Evaluation, pages 1604-1609, Istanbul, Turkey. European Language Resources Association.

Jacob Devlin, Ming-Wei Chang, Kenton Lee, and Kristina Toutanova. 2019. BERT: Pre-training of deep bidirectional transformers for language understanding. In Proceedings of the 2019 Conference of the North American Chapter of the Association for Computational Linguistics: Human Language Technologies, Volume 1 (Long and Short Papers), pages 4171-4186, Minneapolis, Minnesota, USA. Association for Computational Linguistics.

Philip Durrant. 2015. Lexical Bundles and Disciplinary Variation in University Students' Writing: Mapping the Territories. Applied Linguistics, 38(2):165-193.

Phillip Durrant and Julie Mathews-Aydınlı. 2011. A function-first approach to identifying formulaic language in academic writing. English for Specific Purposes, 30(1):58-72.
Markus Eberts and Adrian Ulges. 2020. Span-based joint entity and relation extraction with transformer pre-training. In the 24th European Conference on Artificial Intelligence, pages 2006-2013, Santiago de Compostela, Spain. IOS Press.

Rajab Esfandiari and Fatima Barbary. 2017. A contrastive corpus-driven study of lexical bundles between english writers and persian writers in psychology research articles. Journal of English for Academic Purposes, 29:21-42.

Stefan Evert. 2005. The statistics of word occurrences. Ph.D. thesis, Universität Stuttgart.

James Fiacco, Elena Cotos, and Carolyn Rosé. 2019. Towards enabling feedback on rhetorical structure with neural sequence models. In Proceedings of the 9th International Conference on Learning Analytics \& Knowledge, pages 310-319, Tempe, Arizona, USA. Association for Computing Machinery.

Dan Hendrycks and Kevin Gimpel. 2017. A baseline for detecting misclassified and out-of-distribution examples in neural networks. In The Fifth International Conference on Learning Representations, Toulon, France.

Dan Hendrycks, Xiaoyuan Liu, Eric Wallace, Adam Dziedzic, Rishabh Krishnan, and Dawn Song. 2020. Pretrained transformers improve out-of-distribution robustness. In Proceedings of the 58th Annual Meeting of the Association for Computational Linguistics, pages 2744-2751, Online. Association for Computational Linguistics.

Kenji Hirohata, Naoaki Okazaki, Sophia Ananiadou, and Mitsuru Ishizuka. 2008. Identifying sections in scientific abstracts using conditional random fields. In Proceedings of the Third International Joint Conference on Natural Language Processing: Volume-I, pages 381-388, Hyderabad, India. Asian Federation of Natural Language Processing.

Ken Hyland. 2008. As can be seen: Lexical bundles and disciplinary variation. English for Specific Purposes, 27(1):4-21.

Ken Hyland and Polly Tse. 2007. Is there an "academic vocabulary?”. TESOL Quarterly, 41(2):235-253.

Kenichi Iwatsuki, Florian Boudin, and Akiko Aizawa. 2020a. An evaluation dataset for identifying communicative functions of sentences in English scholarly papers. In Proceedings of the 12th Language Resources and Evaluation Conference, pages 17051713, Marseille, France. European Language Resources Association.

Kenichi Iwatsuki, Florian Boudin, and Akiko Aizawa. 2020b. Extraction and evaluation of formulaic expressions used in scholarly papers. arXiv:2006.10334. 
Alireza Jalilifar, Seyed Mohammad Ghoreishi, and Seyed Abbas Emam Roodband. 2016. Developing an inventory of core lexical bundles in english research articles: a cross-disciplinary corpus-based study. Journal of World Languages, 3(3):184-203.

Budsaba Kanoksilapatham. 2005. Rhetorical structure of biochemistry research articles. English for Specific Purposes, 24:269-292.

Hannah Kermes. 2012. A methodology for the extraction of information about the usage of formulaic expressions in scientific texts. In Proceedings of the Eighth International Conference on Language Resources and Evaluation (LREC'12), pages 2064-2068, Istanbul, Turkey. European Language Resources Association.

Jason Miin Hwa Lim. 2006. Method sections of management research articles: A pedagogically motivated qualitative study. English for Specific Purposes, 25:282-309.

Jason Miin Hwa Lim. 2010. Commenting on research results in applied linguistics and education: A comparative genre-based investigation. Journal of English for Academic Purposes, 9:280-294.

Dilin Liu. 2012. The most frequently-used multi-word constructions in academic written english: A multicorpus study. English for Specific Purposes, 31:2535 .

Yuanchao Liu, Xin Wang, Ming Liu, and Xiaolong Wang. 2016. Write-righter: An academic writing assistant system. In Proceedings of the Thirtieth AAAI Conference on Artificial Intelligence, pages 43734374, Phoenix, Arizona, USA. Association for the Advancement of Artificial Intelligence.

Rosa Lorés. 2004. On RA abstracts: from rhetorical structure to thematic organisation. English for Specific Purposes, 23(3):280-302.

Xiaofei Lu, Jungwan Yoon, and Olesya Kisselev. 2018. A phrase-frame list for social science research article introductions. Journal of English for Academic Purposes, 36:76-85.

Yi Luan, Luheng He, Mari Ostendorf, and Hannaneh Hajishirzi. 2018. Multi-task identification of entities, relations, and coreference for scientific knowledge graph construction. In Proceedings of the 2018 Conference on Empirical Methods in Natural Language Processing, pages 3219-3232, Brussels, Belgium. Association for Computational Linguistics.

Ron Martinez and Norbert Schmitt. 2012. A phrasal expressions list. Applied Linguistics, 33(3):299-320.

Sayako Maswana, Toshiyuki Kanamaru, and Akira Tajino. 2015. Move analysis of research articles across five engineering fields: What they share and what they do not. Ampersand, 2:1-11.
Atsushi Mizumoto, Sawako Hamatani, and Yasuhiro Imao. 2017. Applying the bundle-move connection approach to the development of an online writing support tool for research articles. Language Learning, 67(4):885-921.

John Morley. n. d. Academic phrasebank.

Mark Neumann, Daniel King, Iz Beltagy, and Waleed Ammar. 2019. ScispaCy: Fast and Robust Models for Biomedical Natural Language Processing. In Proceedings of the 18th BioNLP Workshop and Shared Task, pages 319-327, Florence, Italy. Association for Computational Linguistics.

Ismet Ozturk. 2007. The textual organisation of research article introductions in applied linguistics: Variability within a single discipline. English for Specific Purposes, 26(1):25-38.

Fan Pan, Randi Reppen, and Douglas Biber. 2016. Comparing patterns of 11 versus 12 english academic professionals: Lexical bundles in telecommunications research journals. Journal of English for Academic Purposes, 21:60-71.

Matthew Peacock. 2002. Communicative moves in the discussion section of research articles. System, 30:479-497.

Peng Qi, Timothy Dozat, Yuhao Zhang, and Christopher D. Manning. 2018. Universal dependency parsing from scratch. In Proceedings of the CoNLL 2018 Shared Task: Multilingual Parsing from Raw Text to Universal Dependencies, pages 160-170, Brussels, Belgium. Association for Computational Linguistics.

Naser Rashidi and Hussein Meihami. 2018. Informetrics of scientometrics abstracts: a rhetorical move analysis of the research abstracts published in scientometrics journal. Scientometrics, 116:1975-1994.

Dan Roth and Wen-tau Yih. 2004. A linear programming formulation for global inference in natural language tasks. In Proceedings of the Eighth Conference on Computational Natural Language Learning (CoNLL-2004) at HLT-NAACL 2004, pages 1-8, Boston, Massachusetts, USA. Association for Computational Linguistics.

Fahimeh Saboori and Mohammad Reza Hashemi. 2013. A cross-disciplinary move analysis of research article abstracts. International Journal of Language Learning and Applied Linguistics World, 4(4):483496.

Rita Simpson-Vlach and Nick C. Ellis. 2010. An Academic Formulas List: New Methods in Phraseology Research. Applied Linguistics, 31(4):487-512.

Tasanawan Soonklang. 2016. Move classification in scientific abstracts using linguistic features. In The Eleventh International Symposium on Natural Language Processing, Phranakhon Si Ayutthaya, Thailand. 
John Malcolm Swales. 1990. Genre Analysis: English in academic and research settings. Cambridge University Press.

John Malcolm Swales. 2004. Research Genres: Explorations and Applications. Cambridge University Press.

Simone Teufel. 1999. Argumentative Zoning: Information Extraction from Scientific Text. Ph.D. thesis, University of Edinburgh.

Simone Teufel, Advaith Siddharthan, and Colin Batchelor. 2009. Towards domain-independent argumentative zoning: Evidence from chemistry and computational linguistics. In Proceedings of the 2009 Conference on Empirical Methods in Natural Language Processing, pages 1493-1502, Singapore. Association for Computational Linguistics.

Benet Vincent. 2013. Investigating academic phraseology through combinations of very frequent words: A methodological exploration. Journal of English for Academic Purposes, 12(1):44-56.

\section{A Dataset and Databases}

On our website ${ }^{9}$, we published the following dataset and databases:

1. The CF-labelled sentence dataset for training and evaluation,

2. The CF-labelled sentence database, which was constructed by applying SciBERT classifier to every sentence in the corpora we used, and

3. The CF-labelled FE database, which was constructed by applying the proposed FE extraction method to the CF-labelled sentence database.

These data were formatted in tab-separated text. In the CF-labelled sentence dataset, a line consists of an ID and a sentence. In the CF-labelled sentence database, a line consists of a sentence ID (from the corpora), an ID, the maximum softmax value, and a sentence. In the CF-labelled FE database, a line consists of a $\mathrm{CF}$, an $\mathrm{FE}$, and the number of appearance in the corpus.

\section{B CF Set}

Table 13 lists the CF we used. The ID in the table corresponds to the ID used in the sentence dataset and database.

\footnotetext{
${ }^{9}$ https://iwa2ki.com/FE/
}

\section{General and Discipline-Specific FEs}

General FEs are FEs that appear commonly in multiple disciplines. We calculated the average rank of each FE and Table 14 lists the top-5 general FEs for each CF. For most of the CFs, general FEs were not found. We also calculated the odds ratio and Table 15 lists the top-5 discipline-specific FEs for each CF. Some CFs did not happen in a corpus. 


\begin{tabular}{lrl}
\hline Section & ID & CF \\
\hline introduction & 0 & Showing the importance of the topic \\
introduction & 1 & Showing the main problem in the field \\
introduction & 2 & Showing what is already done in the past work \\
introduction & 3 & Showing controversy within the field \\
introduction & 4 & Showing limitation or lack of past work \\
introduction & 5 & Showing the aim of the paper \\
introduction & 6 & Showing brief introduction to the methodology \\
introduction & 7 & Showing the importance of the research \\
introduction & 8 & Showing the limitation of the research \\
introduction & 9 & Showing the outline of the paper \\
introduction & 10 & Showing explanation or definition of terms or notations \\
method & 0 & Showing methodology used in past work \\
method & 1 & Showing reasons why a method was adopted or rejected \\
method & 2 & Using methods used in past work \\
method & 3 & Showing the characteristics of samples or data \\
method & 4 & Showing criteria for selection \\
method & 5 & Description of the process \\
result & 0 & Restatement of the aim or method \\
result & 1 & Reference to tables or figures \\
result & 2 & Description of the results \\
result & 3 & Describing interesting or surprising results \\
result & 4 & Comparison of the results \\
result & 5 & Summary of the results \\
discussion & 0 & Showing background provided by past work \\
discussion & 1 & Restatement of the results \\
discussion & 2 & Unexpected outcome \\
discussion & 3 & Comparison of the results and past work \\
discussion & 4 & Explanation for findings \\
discussion & 5 & Suggestion of hypothesis \\
discussion & 6 & Implications of the findings \\
discussion & 7 & Comments on the findings \\
discussion & 8 & Suggestion of future work \\
\hline & &
\end{tabular}

Table 13: CF list.

\begin{tabular}{|c|c|}
\hline $\mathrm{CF}$ & FE \\
\hline \multicolumn{2}{|l|}{ Section: Introduction } \\
\hline Showing the importance of the topic & plays an important role in \\
\hline Showing the importance of the topic & play an important role in \\
\hline Showing the importance of the topic & also plays an important role in \\
\hline Showing the importance of the topic & is related to \\
\hline Showing the importance of the topic & plays a crucial role in \\
\hline Showing limitation or lack of past work & to the best of our knowledge there is no \\
\hline Showing limitation or lack of past work & to the best of our knowledge no \\
\hline Showing the importance of the research & to the best of our knowledge this is the first \\
\hline Showing brief introduction to the methodology & is based on \\
\hline Showing brief introduction to the methodology & is based on the \\
\hline Showing brief introduction to the methodology & are based on \\
\hline Showing brief introduction to the methodology & is to use \\
\hline Showing the outline of the paper & the paper is organized as follows \\
\hline
\end{tabular}




\begin{tabular}{|c|c|}
\hline $\mathrm{CF}$ & FE \\
\hline Showing the outline of the paper & this paper is organized as follows \\
\hline Showing the outline of the paper & the paper is structured as follows \\
\hline Showing the outline of the paper & this paper is structured as follows \\
\hline Showing the outline of the paper & the rest of the paper is structured as follows \\
\hline \multicolumn{2}{|l|}{ Section: Results } \\
\hline Description of the results & there was no significant difference in \\
\hline Description of the results & we found that the \\
\hline Description of the results & there was no significant difference between the \\
\hline Description of the results & there was no significant difference between \\
\hline Description of the results & we found that \\
\hline Restatement of the aim or method & we used the \\
\hline Restatement of the aim or method & we compared the \\
\hline Restatement of the aim or method & we used a \\
\hline Restatement of the aim or method & we performed a \\
\hline Restatement of the aim or method & was performed using \\
\hline Reference to tables or figures & as shown in \\
\hline Describing interesting or surprising results & it is interesting to note that \\
\hline Describing interesting or surprising results & it is interesting to note that the \\
\hline Summary of the results & these results suggest that \\
\hline Summary of the results & this suggests that \\
\hline Summary of the results & this suggests that the \\
\hline Summary of the results & this indicates that the \\
\hline \multicolumn{2}{|l|}{ Section: Discussion } \\
\hline Restatement of the results & we found that the \\
\hline Restatement of the results & we found that \\
\hline Restatement of the results & it is interesting to note that \\
\hline Restatement of the results & it is worth noting that the \\
\hline Restatement of the results & it is important to note that the \\
\hline Suggestion of hypothesis & our results suggest that \\
\hline Explanation for findings & can be explained by the fact that \\
\hline Explanation for findings & this is due to the fact that \\
\hline Unexpected outcome & it is not surprising that the \\
\hline Implications of the findings & this raises the possibility that \\
\hline
\end{tabular}

Table 14: General FEs.

\begin{tabular}{|c|c|c|c|}
\hline CL & Chem & Onc & Psy \\
\hline \multicolumn{4}{|l|}{ Section: Introduction } \\
\hline \multicolumn{4}{|c|}{ CF: Showing limitation or lack of past work } \\
\hline $\begin{array}{l}\text { to the best of our } \\
\text { knowledge there }\end{array}$ & $\begin{array}{l}\text { to the best of our } \\
\text { knowledge there }\end{array}$ & $\begin{array}{l}\text { however } * \text { role } * \text { re- } \\
\text { mains unclear }\end{array}$ & $\begin{array}{l}\text { to our knowledge only } \\
\text { one study }\end{array}$ \\
\hline $\begin{array}{l}\text { few attempts have been } \\
\text { made to }\end{array}$ & $\begin{array}{l}\text { to the best of our } \\
\text { knowledge there have } \\
\text { been }\end{array}$ & $\begin{array}{l}\text { however } * \text { role } * \text { re- } \\
\text { mains unknown }\end{array}$ & $\begin{array}{l}\text { best of our knowledge } \\
\text { no study has }\end{array}$ \\
\hline $\begin{array}{l}\text { there has been little } \\
\text { work on }\end{array}$ & $\begin{array}{l}\text { to the best of our } \\
\text { knowledge there are } \\
\text { few }\end{array}$ & $\begin{array}{l}\text { remains to be eluci- } \\
\text { dated }\end{array}$ & $\begin{array}{l}\text { only a few studies have } \\
\text { investigated }\end{array}$ \\
\hline there is no & has not been reported & $\begin{array}{l}\text { however } * \text { mechanism } \\
* \text { remains unclear }\end{array}$ & $\begin{array}{l}\text { little attention has been } \\
\text { paid to }\end{array}$ \\
\hline
\end{tabular}




\begin{tabular}{|c|c|c|c|}
\hline CL & Chem & Onc & Psy \\
\hline it is not clear how to & $\begin{array}{l}\text { to the best of our } \\
\text { knowledge the }\end{array}$ & has no & studies $*$ are scarce \\
\hline \multicolumn{4}{|c|}{ CF: Showing the importance of the topic } \\
\hline is an important task in & has been used in & $\begin{array}{l}\text { is one of the most com- } \\
\text { mon }\end{array}$ & $\begin{array}{l}\text { it is important to note } \\
\text { that }\end{array}$ \\
\hline $\begin{array}{l}\text { there has been a grow- } \\
\text { ing interest in }\end{array}$ & $\begin{array}{l}\text { is one of the most pop- } \\
\text { ular }\end{array}$ & et al reported that & is that the \\
\hline $\begin{array}{l}\text { in this work we are in- } \\
\text { terested in }\end{array}$ & belongs to the family & et al found that & $\begin{array}{l}\text { there is a growing body } \\
\text { of research }\end{array}$ \\
\hline $\begin{array}{l}\text { has received a lot of at- } \\
\text { tention }\end{array}$ & is used as a & et al showed that & is defined as a $*$ cite- \\
\hline $\begin{array}{l}\text { the main contribution } \\
\text { of this paper is }\end{array}$ & is widely distributed in & $\begin{array}{l}\text { in this } \\
\text { that }\end{array}$ & $\begin{array}{l}\text { refers to the extent to } \\
\text { which }\end{array}$ \\
\hline \multicolumn{4}{|c|}{ CF: Showing controversy within the field } \\
\hline the state of the art in & $\begin{array}{l}\text { it should be noted that } \\
\text { the }\end{array}$ & role & $\begin{array}{l}\text { is still a matter of de- } \\
\text { bate }\end{array}$ \\
\hline $\begin{array}{l}\text { this research was par- } \\
\text { tially supported by }\end{array}$ & it should be noted that & $\begin{array}{l}\text { is still a matter of de- } \\
\text { bate }\end{array}$ & is an open question \\
\hline $\begin{array}{l}\text { this work was sup- } \\
\text { ported by the }\end{array}$ & $\begin{array}{l}\text { it is important to men- } \\
\text { tion that }\end{array}$ & $\begin{array}{l}\text { this has led to the sug- } \\
\text { gestion that }\end{array}$ & $\begin{array}{l}\text { the question arises as to } \\
\text { whether }\end{array}$ \\
\hline $\begin{array}{l}\text { the current state of the } \\
\text { art }\end{array}$ & $\begin{array}{l}\text { it is worth mentioning } \\
\text { that the }\end{array}$ & r debate & $\begin{array}{l}\text { are still a matter of de- } \\
\text { bate }\end{array}$ \\
\hline $\begin{array}{l}\text { this work was done } \\
\text { while the }\end{array}$ & $\begin{array}{l}\text { it should be noted how- } \\
\text { ever that }\end{array}$ & & $\begin{array}{l}\text { it remains an open } \\
\text { question whether }\end{array}$ \\
\hline \multicolumn{4}{|c|}{ CF: Showing the aim of the paper } \\
\hline $\begin{array}{l}\text { in this paper we focus } \\
\text { on } \\
\text { in this paper we pro- } \\
\text { pose a novel }\end{array}$ & $\begin{array}{l}\text { the aim of this study } \\
\text { was to } \\
\text { objective of this study } \\
\text { was to }\end{array}$ & $\begin{array}{l}\text { the aim of this study } \\
\text { was to } \\
\text { purpose of this study } \\
\text { was to }\end{array}$ & $\begin{array}{l}\text { the aim of the present } \\
\text { study was to } \\
\text { the aim of the present } \\
\text { study was to investi- } \\
\text { gate }\end{array}$ \\
\hline $\begin{array}{l}\text { in this paper we pro- } \\
\text { pose a }\end{array}$ & $\begin{array}{l}\text { the aim of this work } \\
\text { was to }\end{array}$ & $\begin{array}{l}\text { aim of this study was } \\
\text { to investigate the }\end{array}$ & $\begin{array}{l}\text { the aim of this study } \\
\text { was to }\end{array}$ \\
\hline $\begin{array}{l}\text { in this paper we present } \\
\text { an }\end{array}$ & $\begin{array}{l}\text { in this paper we report } \\
\text { the }\end{array}$ & $\begin{array}{l}\text { the aim of the present } \\
\text { study was to }\end{array}$ & $\begin{array}{l}\text { the aim of the present } \\
\text { study was to examine }\end{array}$ \\
\hline $\begin{array}{l}\text { in this paper we pro- } \\
\text { pose an }\end{array}$ & $\begin{array}{l}\text { the aim of the present } \\
\text { study was to }\end{array}$ & $\begin{array}{l}\text { purpose of this study } \\
\text { was to investigate the }\end{array}$ & $\begin{array}{l}\text { the purpose of the } \\
\text { present study was to }\end{array}$ \\
\hline \multicolumn{4}{|c|}{ CF: Showing the importance of the research } \\
\hline we propose a novel & $\begin{array}{l}\text { to our knowledge this } \\
\text { is the first report on }\end{array}$ & $\begin{array}{l}\text { we show for the first } \\
\text { time that }\end{array}$ & $\begin{array}{l}\text { to our knowledge the } \\
\text { present study is the first }\end{array}$ \\
\hline we propose a new & $\begin{array}{l}\text { to the best of our } \\
\text { knowledge this is the } \\
\text { first time }\end{array}$ & $\begin{array}{l}\text { in this study we } * \text { for } \\
\text { the first time that }\end{array}$ & $\begin{array}{l}\text { to our knowledge this } \\
\text { is the first study to }\end{array}$ \\
\hline $\begin{array}{l}\text { to the best of our } \\
\text { knowledge we are the } \\
\text { first }\end{array}$ & $\begin{array}{l}\text { to our knowledge this } \\
\text { is the first time that }\end{array}$ & $\begin{array}{l}\text { we demonstrate for the } \\
\text { first time that }\end{array}$ & $\begin{array}{l}\text { best of our knowledge } \\
\text { the present study is }\end{array}$ \\
\hline we present a novel & was reported in $*$ cite- & $\begin{array}{l}\text { we report for the first } \\
\text { time that }\end{array}$ & $\begin{array}{l}\text { should be able to dis- } \\
\text { criminate between }\end{array}$ \\
\hline we $p$ & was & $\begin{array}{l}\text { here we show for the } \\
\text { first time that }\end{array}$ & $\begin{array}{l}\text { as far as we are aware } \\
* \text { is the first }\end{array}$ \\
\hline
\end{tabular}




\begin{tabular}{|c|c|c|}
\hline $\mathrm{CL}$ & Chem & Psy \\
\hline is not limited to & $\begin{array}{l}\text { beyond the scope of } \\
\text { this review }\end{array}$ & $\begin{array}{l}\text { beyond the scope of } \\
\text { this paper } \\
\text { beyond the scope of } \\
\text { this article } \\
\text { in the absence of any * } \\
\text { that could be } \\
\text { is the focus of this } \\
\text { study }\end{array}$ \\
\hline
\end{tabular}

\begin{tabular}{|c|c|c|c|}
\hline \multicolumn{4}{|c|}{ CF: Showing brief introduction to the methodology } \\
\hline $\begin{array}{l}\text { page numbers and } \\
\text { proceedings footer are } \\
\text { added }\end{array}$ & were characterized by & $\begin{array}{l}\text { in this study we inves- } \\
\text { tigated the }\end{array}$ & $\begin{array}{l}\text { in the present study we } \\
\text { focus on }\end{array}$ \\
\hline we evaluate our & were also investigated & $\begin{array}{l}\text { in the present study we } \\
\text { investigated the }\end{array}$ & $\begin{array}{l}\text { in the present study we } \\
\text { investigated }\end{array}$ \\
\hline cite- proposed a & was used as the & $\begin{array}{l}\text { in this study we aimed } \\
\text { to }\end{array}$ & cite- cite- cite- cite- \\
\hline section 3 describes the & et al cite- used & $\begin{array}{l}\text { in this study we evalu- } \\
\text { ated the }\end{array}$ & et al cite- used \\
\hline we propose a & was used as a & $\begin{array}{l}\text { in this study we inves- } \\
\text { tigated the role of }\end{array}$ & $\begin{array}{l}\text { the present study was } \\
\text { designed to }\end{array}$ \\
\hline \multicolumn{4}{|c|}{ CF: Showing the main problem in the field } \\
\hline is that the & $\begin{array}{l}\text { is one of the most com- } \\
\text { mon }\end{array}$ & is the leading cause of & $\begin{array}{l}\text { is one of the most com- } \\
\text { mon }\end{array}$ \\
\hline $\begin{array}{l}\text { is a fundamental prob- } \\
\text { lem in }\end{array}$ & $\begin{array}{l}\text { is the most common } \\
\text { form of }\end{array}$ & $\begin{array}{l}\text { is the second leading } \\
\text { cause of }\end{array}$ & $\begin{array}{l}\text { there are two reasons } \\
\text { for this }\end{array}$ \\
\hline is the lack of & $\begin{array}{l}\text { is one of the most seri- } \\
\text { ous }\end{array}$ & $\begin{array}{l}\text { is the third leading } \\
\text { cause of }\end{array}$ & however is that \\
\hline there are two main & $\begin{array}{l}\text { therefore it is necessary } \\
\text { to develop }\end{array}$ & $\begin{array}{l}\text { is the leading cause of } \\
\text { death }\end{array}$ & $\begin{array}{l}\text { this is one of the rea- } \\
\text { sons why the }\end{array}$ \\
\hline $\begin{array}{l}\text { the main contribution } \\
\text { of this work is }\end{array}$ & $\begin{array}{l}\text { is one of the most fre- } \\
\text { quent }\end{array}$ & $\begin{array}{l}\text { there is an urgent need } \\
\text { to identify }\end{array}$ & $\begin{array}{l}\text { for this reason it is nec- } \\
\text { essary to }\end{array}$ \\
\hline \multicolumn{4}{|c|}{ CF: Showing explanation or definition of terms or notations } \\
\hline $\begin{array}{l}\text { we call this } \\
\text { we call such } \\
\text { is called a } \\
\text { is called the } \\
\text { we denote by }\end{array}$ & $\begin{array}{l}\text { is defined as a* cite- } \\
\text { are defined as * cite- } \\
\text { is defined as }\end{array}$ & $\begin{array}{l}\text { are defined as } * \text { cite- } \\
\text { is also called } \\
\text { is defined as a } * \text { cite- } \\
\text { hereafter referred to as } \\
\text { is defined as } * \text { cite- }\end{array}$ & $\begin{array}{l}\text { refers to } * \text { cite- } \\
\text { refers to the * cite- } \\
\text { this is referred to as the } \\
\text { is often referred to as } \\
\text { refer to } * \text { cite- }\end{array}$ \\
\hline \multicolumn{4}{|c|}{ CF: Showing what is already done in the past work } \\
\hline have been applied to & have been used as & cite- cite- cite- & et al cite \\
\hline have been proposed for & $\begin{array}{l}\text { have been isolated } \\
\text { from }\end{array}$ & $\begin{array}{l}\text { accumulating evidence } \\
\text { suggests that }\end{array}$ & and $*$ cite- \\
\hline $\begin{array}{l}\text { have been developed } \\
\text { for }\end{array}$ & et al reported that & $\begin{array}{l}\text { increasing evidence } \\
\text { suggests that }\end{array}$ & et al cite- found that \\
\hline have been proposed & have been used in & $\begin{array}{l}\text { several lines of evi- } \\
\text { dence suggest that }\end{array}$ & $\begin{array}{l}\text { for example it has been } \\
\text { shown that }\end{array}$ \\
\hline $\begin{array}{l}\text { there have been a num- } \\
\text { ber of }\end{array}$ & $\begin{array}{l}\text { have been reported cite- } \\
\text { cite- } * \text { cite- cite- cite- }\end{array}$ & $\begin{array}{l}\text { a growing body of evi- } \\
\text { dence suggests that }\end{array}$ & $\begin{array}{l}\text { it has been argued that } \\
\text { the }\end{array}$ \\
\hline
\end{tabular}




\begin{tabular}{|c|c|c|c|}
\hline CL & Chem & Onc & Psy \\
\hline $\begin{array}{l}\text { of this paper is orga- } \\
\text { nized as follows } \\
\text { the rest of * paper is or- } \\
\text { ganized as follows }\end{array}$ & & & $\begin{array}{l}\text { the rest of the paper is } \\
\text { organized as follows } \\
\text { the remainder of the pa- } \\
\text { per is organized as fol- } \\
\text { lows }\end{array}$ \\
\hline remainder of this paper & & & the rest of this paper is \\
\hline is structured as follows & & & organized as follows \\
\hline paper is organized as & & & can be divided into \\
\hline $\begin{array}{l}\text { follows section } 2 \\
\text { the contributions of }\end{array}$ & & & remainder of this paper \\
\hline $\begin{array}{l}\text { this paper are as fol- } \\
\text { lows }\end{array}$ & & & is organized as follows \\
\hline \multicolumn{4}{|l|}{ Section: Methods } \\
\hline \multicolumn{4}{|c|}{ CF: Using methods used in past work } \\
\hline we propose a & $\begin{array}{l}\text { the title compound was } \\
\text { prepared from }\end{array}$ & $\begin{array}{l}\text { was performed as pre- } \\
\text { viously described cite- }\end{array}$ & $\begin{array}{l}\text { was calculated using } \\
\text { the }\end{array}$ \\
\hline is based on & $\begin{array}{l}\text { characterization data is } \\
\text { in accordance with that } \\
\text { reported in cite- }\end{array}$ & $\begin{array}{l}\text { were performed as pre- } \\
\text { viously described cite- }\end{array}$ & was based on the \\
\hline is based on the & $\begin{array}{l}\text { was calculated accord- } \\
\text { ing to the following } \\
\text { equation }\end{array}$ & $\begin{array}{l}\text { was performed as de- } \\
\text { scribed previously cite- }\end{array}$ & was adapted from cite- \\
\hline $\begin{array}{l}\text { in this section we de- } \\
\text { scribe our }\end{array}$ & $\begin{array}{l}\text { was calculated using } \\
\text { the following equation }\end{array}$ & $\begin{array}{l}\text { were performed as de- } \\
\text { scribed previously cite- }\end{array}$ & is based on the \\
\hline is based on a & $\begin{array}{l}\text { was prepared accord- } \\
\text { ing to the general pro- } \\
\text { cedure }\end{array}$ & $\begin{array}{l}\text { conducted in accor- } \\
\text { dance with the * ac- } \\
\text { cording to the }\end{array}$ & was developed by cite- \\
\hline \multicolumn{4}{|c|}{ CF: Showing reasons why a method was adopted or rejected } \\
\hline is used for & was used for & $\begin{array}{l}\text { was used to analyze the } \\
\text { relationship between }\end{array}$ & was used to assess \\
\hline are used for & $\begin{array}{l}\text { was used as a positive } \\
\text { control }\end{array}$ & $\begin{array}{l}\text { was used to evalu- } \\
\text { ate the association be- } \\
\text { tween }\end{array}$ & was used to measure \\
\hline can be used for & was used for the & $\begin{array}{l}\text { was used to analyze the } \\
\text { correlation between }\end{array}$ & $\begin{array}{l}\text { et al cite- was used to } \\
\text { assess }\end{array}$ \\
\hline is used as the & was used as the & $\begin{array}{l}\text { was used to assess the } \\
\text { association between }\end{array}$ & version * was used \\
\hline is that the & were used for & were used to estimate & $\begin{array}{l}\text { was used as a measure } \\
\text { of }\end{array}$ \\
\hline \multicolumn{4}{|c|}{ CF: Showing the characteristics of samples or data } \\
\hline are shown in table 1 & are listed in cite- & $\begin{array}{l}\text { experiments were re- } \\
\text { peated at least three } \\
\text { times }\end{array}$ & all participants had \\
\hline are added to the & are shown in cite- & $\begin{array}{l}\text { all experiments were } \\
\text { performed in triplicate }\end{array}$ & $\begin{array}{l}\text { had normal or cor- } \\
\text { rected to normal vision }\end{array}$ \\
\hline $\begin{array}{l}\text { submission are marked } \\
\text { with an asterisk }\end{array}$ & $\begin{array}{l}\text { used in this study are } \\
\text { listed in cite- }\end{array}$ & $\begin{array}{l}\text { of at least three inde- } \\
\text { pendent experiments }\end{array}$ & $\begin{array}{l}\text { ranged in age from } 18 \\
\text { to }\end{array}$ \\
\hline are listed in table 1 & $\begin{array}{l}\text { were used as positive } \\
\text { controls }\end{array}$ & $\begin{array}{l}\text { each experiment was } \\
\text { performed in triplicate }\end{array}$ & $\begin{array}{l}\text { participants * were ex- } \\
\text { cluded }\end{array}$ \\
\hline
\end{tabular}




\begin{tabular}{|c|c|c|c|}
\hline CL & Chem & Onc & Psy \\
\hline are shown in table 2 & $\begin{array}{l}\mathrm{s} \text { singlet } \mathrm{d} \text { doublet } \mathrm{t} \\
\text { triplet }\end{array}$ & $\begin{array}{l}\text { experiment was re- } \\
\text { peated at least three } \\
\text { times }\end{array}$ & $\begin{array}{l}\text { all participants were } \\
\text { native speakers of }\end{array}$ \\
\hline \multicolumn{4}{|c|}{ CF: Showing methodology used in past work } \\
\hline we use two & include $*$ cite- & is how to formulate a & et al cite- \\
\hline we adopt a & $\begin{array}{l}\text { has been routinely and } \\
\text { widely used in }\end{array}$ & $\begin{array}{l}\text { has been widely recog- } \\
\text { nized and increasingly } \\
* \text { to examine the qual- } \\
\text { ity of } * \text { see eg cite- }\end{array}$ & and $*$ cite- \\
\hline we use the following & cite- cite- cite- & here the $*$ ratio & $\begin{array}{l}\text { has been shown to have } \\
\text { good }\end{array}$ \\
\hline we consider two & cite- lists the & $\begin{array}{l}\text { described in cite- } * \\
\text { there is no need to re- } \\
\text { peat }\end{array}$ & $\begin{array}{l}\text { it should be noted that } \\
\text { the }\end{array}$ \\
\hline there are two & $\begin{array}{l}\text { is one of the most } \\
\text { widely used }\end{array}$ & $\begin{array}{l}\text { are needed as elabo- } \\
\text { rated in cite- }\end{array}$ & has been shown to be a \\
\hline \multicolumn{4}{|c|}{ CF: Showing criteria for selection } \\
\hline figure 1 the & were maintained in & $\begin{array}{l}\text { p } 005 \text { was considered } \\
\text { statistically significant }\end{array}$ & was defined as \\
\hline is shown in figure 1 & $\begin{array}{l}\text { was defined as the } \\
\text { amount of enzyme }\end{array}$ & $\begin{array}{l}\mathrm{p} \text { values } 005 \text { were con- } \\
\text { sidered statistically sig- } \\
\text { nificant }\end{array}$ & was defined as the \\
\hline figure 2 the & $\begin{array}{l}\text { was defined as the low- } \\
\text { est concentration of }\end{array}$ & $\begin{array}{l}005 \text { was considered to } \\
\text { be statistically signifi- } \\
\text { cant }\end{array}$ & $\begin{array}{l}\text { were selected from the } \\
* \text { cite- }\end{array}$ \\
\hline figure $1 \mathrm{a}$ & $\begin{array}{l}\text { in accordance with the } \\
* \text { care and use of labo- } \\
\text { ratory animals }\end{array}$ & $\begin{array}{l}\text { p } 005 \text { was considered } \\
\text { significant }\end{array}$ & is defined as \\
\hline is a set of & cells were cultured in & $\begin{array}{l}\text { value * was considered } \\
\text { statistically significant }\end{array}$ & were defined as \\
\hline \multicolumn{4}{|c|}{ CF: Description of the process } \\
\hline we assume that the & $\begin{array}{l}\text { was stirred at room } \\
\text { temperature for }\end{array}$ & were purchased from & $\begin{array}{l}\text { study was carried out } \\
\text { in accordance with the }\end{array}$ \\
\hline we calculate the & hrms mz m h calcd & was used for & $\begin{array}{l}\text { gave written informed } \\
\text { consent in accordance } \\
\text { with the }\end{array}$ \\
\hline $\begin{array}{l}\text { we also use } \\
\text { we then use the }\end{array}$ & $\begin{array}{l}\text { were recorded on an } \\
\text { were purchased from }\end{array}$ & $\begin{array}{l}\text { was purchased from } \\
\text { were maintained in }\end{array}$ & $\begin{array}{l}\text { was approved by the } \\
\text { study was approved by } \\
\text { the ethics committee of }\end{array}$ \\
\hline are trained using & $\begin{array}{l}\text { the mixture was stirred } \\
\text { for }\end{array}$ & were used for & $\begin{array}{l}\text { gave written informed } \\
\text { consent in accordance } \\
\text { with the declaration of } \\
\text { helsinki }\end{array}$ \\
\hline \multicolumn{4}{|l|}{ Section: Results } \\
\hline \multicolumn{4}{|c|}{ CF: Comparison of the results } \\
\hline we compare our & cite- compares the & analysis of the & $\begin{array}{l}\text { at each measurement } \\
\text { point showed that }\end{array}$ \\
\hline we compare the & $\begin{array}{l}\text { comparison } * \text { is shown } \\
\text { in cite- }\end{array}$ & comparison of the & $\begin{array}{l}\text { in this section we } \\
\text { present the }\end{array}$ \\
\hline
\end{tabular}




\begin{tabular}{|c|c|c|c|}
\hline CL & Chem & Onc & Psy \\
\hline table 3 comparison of & a comparison of the & $\begin{array}{l}\text { comparison of } * \text { re- } \\
\text { vealed }\end{array}$ & $\begin{array}{l}\text { conditions there was an } \\
\text { effect of condition with }\end{array}$ \\
\hline table 2 comparison of & $\begin{array}{l}\text { summary } * \text { is pre- } \\
\text { sented in cite- }\end{array}$ & rison of $*$ cite- & 1 \\
\hline table 1 comparison of & $\begin{array}{l}\text { cite- shows the compar- } \\
\text { ison of }\end{array}$ & analysis of the * cite- & $\begin{array}{l}\text { inspection } * \text { indicated } \\
\text { a significant influence } \\
\text { of }\end{array}$ \\
\hline \multicolumn{4}{|c|}{ CF: Reference to tables or figures } \\
\hline $\begin{array}{l}\text { table } 2 \text { shows the } \\
\text { table } 1 \text { shows the }\end{array}$ & $\begin{array}{l}\text { cite- shows the } \\
\text { are shown in cite- }\end{array}$ & $\begin{array}{l}\text { as shown in figure cite- } \\
\text { figure cite- shows the }\end{array}$ & $\begin{array}{l}\text { figure cite- shows the } \\
\text { are presented in table } \\
\text { cite- }\end{array}$ \\
\hline $\begin{array}{l}\text { table } 3 \text { shows the } \\
\text { results are shown in ta- } \\
\text { hle? }\end{array}$ & $\begin{array}{l}\text { it can be seen that the } \\
\text { the results are shown in }\end{array}$ & $\begin{array}{l}\text { are shown in table cite- } \\
\text { are summarized in ta- }\end{array}$ & $\begin{array}{l}\text { table cite- shows the } \\
\text { are shown in table cite- }\end{array}$ \\
\hline figure 2 shows the & is shown in cite- & $\begin{array}{l}\text { are shown in figure } \\
\text { cite- }\end{array}$ & tab \\
\hline \multicolumn{4}{|c|}{ CF: Description of the results } \\
\hline achieves & $\begin{array}{l}\text { et al cite- reported that } \\
\text { the }\end{array}$ & $\begin{array}{l}\text { it has been reported } \\
\text { that }\end{array}$ & $\begin{array}{l}\text { ignificant } \\
\mathrm{f}\end{array}$ \\
\hline performs better than & $\begin{array}{l}\text { indicated the presence } \\
\text { of }\end{array}$ & our results showed that & $\begin{array}{l}\text { significant } \\
\text { of }\end{array}$ \\
\hline $\begin{array}{l}\text { significantly outper- } \\
\text { form the }\end{array}$ & was determined to be & was observed in & $\begin{array}{l}\text { showed a significant } \\
\text { main effect of }\end{array}$ \\
\hline $\begin{array}{l}\text { is significantly better } \\
\text { than the }\end{array}$ & was & $\begin{array}{l}\text { we have previously } \\
\text { shown that }\end{array}$ & $\begin{array}{l}\text { there was a significant } \\
\text { interaction between }\end{array}$ \\
\hline outperforms all other & was & te- & $\begin{array}{l}\text { there } \mathrm{v} \\
\text { of }\end{array}$ \\
\hline \multicolumn{4}{|c|}{ CF: Describing interesting or surprising results } \\
\hline $\begin{array}{l}\text { this is due to the fact } \\
\text { that }\end{array}$ & ting that & $\begin{array}{l}\text { interestingly we found } \\
\text { that }\end{array}$ & \\
\hline $\begin{array}{l}\text { is due to the fact that } \\
\text { the }\end{array}$ & $\begin{array}{l}\text { it is important to men- } \\
\text { tion that }\end{array}$ & $\begin{array}{l}\text { interestingly we ob- } \\
\text { served that }\end{array}$ & $\begin{array}{l}\text { it should be noted that } \\
\text { the }\end{array}$ \\
\hline $\begin{array}{l}\text { it should be noted that } \\
\text { the }\end{array}$ & rth mentioning & found that & and $*$ cite- \\
\hline we call this & $\begin{array}{l}\text { best of our knowledge } \\
\text { this is the first report }\end{array}$ & $\begin{array}{l}\text { interestingly we found } \\
\text { that the }\end{array}$ & $\begin{array}{l}\text { however it is important } \\
\text { to note that }\end{array}$ \\
\hline $\begin{array}{l}\text { this can be explained } \\
\text { by the fact that }\end{array}$ & $\begin{array}{l}\text { it is im } \\
\text { that }\end{array}$ & $r *$ figure cite- & \\
\hline \multicolumn{4}{|c|}{ CF: Summary of the results } \\
\hline this shows that our & $\begin{array}{l}\text { the results indicated } \\
\text { that }\end{array}$ & $\begin{array}{l}\text { taken together these } \\
\text { data demonstrate that }\end{array}$ & $\begin{array}{l}\text { this indicates that * } \\
\text { likely }\end{array}$ \\
\hline $\begin{array}{l}\text { this result shows that } \\
\text { the proposed }\end{array}$ & $\begin{array}{l}\text { these results are in } \\
\text { agreement with those }\end{array}$ & $\begin{array}{l}\text { taken together these re- } \\
\text { sults demonstrated that }\end{array}$ & $\begin{array}{l}\text { this pattern is consis- } \\
\text { tent with the }\end{array}$ \\
\hline $\begin{array}{l}\text { from these results we } \\
\text { can conclude that }\end{array}$ & $\begin{array}{l}\text { these results are in ac- } \\
\text { cordance with }\end{array}$ & $\begin{array}{l}\text { taken together these } \\
\text { findings indicate that }\end{array}$ & $\begin{array}{l}\text { therefore hypothesis } 3 \\
\text { is supported }\end{array}$ \\
\hline this sugge & this indicated that the & $\begin{array}{l}\text { taken together our data } \\
\text { suggest that }\end{array}$ & $\begin{array}{l}\text { this suggests that dur- } \\
\text { ing both meditation } \\
\text { conditions saline }\end{array}$ \\
\hline $\begin{array}{l}\text { these results demon- } \\
\text { strate that the proposed }\end{array}$ & $\begin{array}{l}\text { the results show t } \\
\text { the }\end{array}$ & $\begin{array}{l}\text { these results suggest } \\
\text { that } * \text { promotes }\end{array}$ & $\begin{array}{l}\text { this suggests that the } * \\
\text { had }\end{array}$ \\
\hline
\end{tabular}




\begin{tabular}{|c|c|c|c|}
\hline $\mathrm{CL}$ & Chem & Onc & Psy \\
\hline \multicolumn{4}{|c|}{ CF: Restatement of the aim or method } \\
\hline we use the & $\begin{array}{l}\text { was used as a positive } \\
\text { control }\end{array}$ & were treated with & was conducted on \\
\hline we use a & was reacted with & was confirmed by & was conducted on the \\
\hline we evaluate our & $\begin{array}{l}\text { was used as the posi- } \\
\text { tive control }\end{array}$ & $\begin{array}{l}\text { investigate } * \text { we per- } \\
\text { formed }\end{array}$ & were submitted to a \\
\hline we evaluate the & $\begin{array}{l}\text { were used as positive } \\
\text { controls }\end{array}$ & $\begin{array}{l}\text { determine } * \text { we per- } \\
\text { formed }\end{array}$ & we conducted a \\
\hline we use the same & $\begin{array}{l}\text { were evaluated for } \\
\text { their }\end{array}$ & $\begin{array}{l}\text { we next examined the } \\
\text { effect of }\end{array}$ & was conducted with \\
\hline \multicolumn{4}{|l|}{ Section: Discussion } \\
\hline \multicolumn{4}{|c|}{ CF: Comparison of the results and past work } \\
\hline $\begin{array}{l}\text { material is based upon } \\
\text { work supported in part } \\
\text { by }\end{array}$ & et al showed that & $\begin{array}{l}\text { et al cite- also reported } \\
\text { that }\end{array}$ & $\begin{array}{l}\text { is in line with previous } \\
\text { research }\end{array}$ \\
\hline $\begin{array}{l}\text { this material is based in } \\
\text { part on research spon- } \\
\text { sored by the }\end{array}$ & et al found that & $\begin{array}{l}\text { our results also showed } \\
\text { that }\end{array}$ & $\begin{array}{l}\text { is in line with previous } \\
\text { studies }\end{array}$ \\
\hline $\begin{array}{l}\text { material is based upon } \\
\text { work supported by the }\end{array}$ & et al demonstrated that & $\begin{array}{l}\text { these findings are con- } \\
\text { sistent with previous re- } \\
\text { ports }\end{array}$ & $\begin{array}{l}\text { these findings are in } \\
\text { line with }\end{array}$ \\
\hline this is also the case for & et al cite- & $\begin{array}{l}\text { our results are consis- } \\
\text { tent with previous }\end{array}$ & $\begin{array}{l}\text { is in line with previous } \\
\text { findings }\end{array}$ \\
\hline $\begin{array}{l}\text { this paper is } * \text { upon } \\
\text { work supported in part } \\
\text { by }\end{array}$ & et al indicated that & $\begin{array}{l}\text { our results are consis- } \\
\text { tent with those }\end{array}$ & $\begin{array}{l}\text { this finding is in line } \\
\text { with }\end{array}$ \\
\hline \multicolumn{4}{|c|}{ CF: Implications of the findings } \\
\hline & & $\begin{array}{l}\text { these findings raise the } \\
\text { possibility that }\end{array}$ & $\begin{array}{l}\text { these findings have } \\
\text { important implications } \\
\text { for }\end{array}$ \\
\hline & & $\begin{array}{l}\text { this suggests the possi- } \\
\text { bility that } \\
\text { these results raise the } \\
\text { possibility that }\end{array}$ & $\begin{array}{l}\text { the present study con- } \\
\text { tributes to the } \\
\text { it is assumed that }\end{array}$ \\
\hline & & $\begin{array}{l}\text { highlights the impor- } \\
\text { tance of } \\
\text { there are several impor- } \\
\text { tant implications in this }\end{array}$ & $\begin{array}{l}\text { limit the generalizabil- } \\
\text { ity of our findings } \\
\text { our findings also have } \\
\text { implications for }\end{array}$ \\
\hline \multicolumn{4}{|c|}{ CF: Restatement of the results } \\
\hline we would like to thank & was found to be & $\begin{array}{l}\text { to the best of our } \\
\text { knowledge this is the } \\
\text { first }\end{array}$ & $\begin{array}{l}\text { it is important to note } \\
\text { that }\end{array}$ \\
\hline $\begin{array}{l}\text { the experimental re- } \\
\text { sults show that our }\end{array}$ & were characterized by & et al found that & the results showed that \\
\hline $\begin{array}{l}\text { experimental results } \\
\text { show that the proposed }\end{array}$ & $\begin{array}{l}\text { was found to be the } \\
\text { most potent }\end{array}$ & $\begin{array}{l}\text { to our knowledge this } \\
\text { is the first }\end{array}$ & cite- found that \\
\hline $\begin{array}{l}\text { in this paper we have } \\
\text { shown that }\end{array}$ & $\begin{array}{l}\text { were tested for their } \\
\text { ability to inhibit }\end{array}$ & $\begin{array}{l}\text { in this study we found } \\
\text { that }\end{array}$ & $\begin{array}{l}\text { we did not find any sig- } \\
\text { nificant }\end{array}$ \\
\hline $\mathrm{i}$ would like to thank & $\begin{array}{l}\text { were evaluated for } \\
\text { their }\end{array}$ & $\begin{array}{l}\text { in this study we demon- } \\
\text { strated that }\end{array}$ & $\begin{array}{l}\text { it is important to note } * \\
\text { the current study }\end{array}$ \\
\hline
\end{tabular}




\begin{tabular}{|c|c|c|c|}
\hline CL & Chem & Onc & Psy \\
\hline \multicolumn{4}{|c|}{ CF: Showing background provided by past work } \\
\hline $\begin{array}{l}\text { in this paper we have } \\
\text { presented a }\end{array}$ & include * cite- & et al reported that & et al cite- \\
\hline $\begin{array}{l}\text { in this paper we pre- } \\
\text { sented a }\end{array}$ & in the present study & $\begin{array}{l}\text { it has been reported } \\
\text { that }\end{array}$ & cite- cite- cite- \\
\hline $\begin{array}{l}\text { in this paper we pro- } \\
\text { pose a }\end{array}$ & $\begin{array}{l}\text { it has been reported } \\
\text { that }\end{array}$ & et al demonstrated that & it has be \\
\hline $\begin{array}{l}\text { in this paper we pro- } \\
\text { posed a }\end{array}$ & $\begin{array}{l}\text { will be reported in due } \\
\text { course }\end{array}$ & it was reported that & $\begin{array}{l}\text { it has been argued that } \\
\text { the }\end{array}$ \\
\hline we presented a & orted that & it ha: & and $*$ cite- \\
\hline \multicolumn{4}{|c|}{ CF: Suggestion of hypothesis } \\
\hline we have presented a & $\begin{array}{l}\text { best of o } \\
\text { this is th }\end{array}$ & study & $\begin{array}{l}\text { this finding supports } \\
\text { the notion that }\end{array}$ \\
\hline $\begin{array}{l}\text { we have presented a } \\
\text { novel }\end{array}$ & $\begin{array}{l}\text { it can be concluded that } \\
\text { the }\end{array}$ & these data & suggests that the \\
\hline we have proposed a & $\begin{array}{l}\text { in summary we have } \\
\text { developed a }\end{array}$ & $\begin{array}{l}\text { in conclusion our data } \\
\text { suggest that }\end{array}$ & $\begin{array}{l}\text { nt findings } \\
\text { at the }\end{array}$ \\
\hline $\begin{array}{l}\text { we have presented a } \\
\text { new }\end{array}$ & $\begin{array}{l}\text { usion we have } \\
\text { d a }\end{array}$ & our results showed that & $\begin{array}{l}\text { this finding supports } \\
\text { the idea that }\end{array}$ \\
\hline $\begin{array}{l}\text { we have shown that it } \\
\text { is possible }\end{array}$ & it is $\mathrm{kn}$ & lits & $\begin{array}{l}\text { the present study pro- } \\
\text { vides the first }\end{array}$ \\
\hline \multicolumn{4}{|c|}{ CF: Comments on the findings } \\
\hline $\begin{array}{l}\text { we have presented a } \\
\text { simple and effective }\end{array}$ & $\begin{array}{l}\text { was successfully ap- } \\
\text { plied to the }\end{array}$ & & \\
\hline we ach & $\begin{array}{l}\text { in summary we have } \\
\text { successfully developed }\end{array}$ & $\begin{array}{l}\text { a promising } \\
\text { for }\end{array}$ & is that the \\
\hline we expect the & $\begin{array}{l}\text { was successfully ap- } \\
\text { plied for the }\end{array}$ & $\begin{array}{l}\text { is a promising strategy } \\
\text { for }\end{array}$ & $\begin{array}{l}\text { on the one hand } * \text { on } \\
\text { the other hand }\end{array}$ \\
\hline $\begin{array}{l}\text { acknowledgements we } \\
\text { are grateful to }\end{array}$ & $\begin{array}{l}\text { has been successfully } \\
\text { applied to the }\end{array}$ & $\begin{array}{l}\text { might be a promising } \\
\text { strategy for }\end{array}$ & $\begin{array}{l}\text { declares that despite } \\
\text { being affiliated to } *\end{array}$ \\
\hline has seve & $\begin{array}{l}\text { has been successfully } \\
\text { applied to a }\end{array}$ & we & esent \\
\hline \multicolumn{4}{|c|}{ CF: Explanation for findings } \\
\hline $\begin{array}{l}\text { this can be explained } \\
\text { by the fact that the }\end{array}$ & can b & & $\begin{array}{l}\text { it should } \\
\text { the }\end{array}$ \\
\hline $\begin{array}{l}\text { this is due to the fact } \\
\text { that the }\end{array}$ & $\begin{array}{l}\text { can be explained by the } \\
\text { presence of }\end{array}$ & $\begin{array}{l}\text { therefore it is possible } \\
\text { that the }\end{array}$ & $\begin{array}{l}\text { however it should be } \\
\text { noted that }\end{array}$ \\
\hline $\begin{array}{l}\text { we believe that this is } \\
\text { due to the }\end{array}$ & $\begin{array}{l}\text { can be attributed to the } \\
\text { presence of }\end{array}$ & $\begin{array}{l}\text { however } * \text { mechanism } \\
* \text { is unclear }\end{array}$ & $\begin{array}{l}\text { it should be noted how- } \\
\text { ever that }\end{array}$ \\
\hline $\begin{array}{l}\text { one reason for this is } \\
\text { that }\end{array}$ & $\begin{array}{l}\text { this could be explained } \\
\text { by the fact that }\end{array}$ & this may explain why & $\begin{array}{l}\text { it is also possible that } \\
\text { the }\end{array}$ \\
\hline $\begin{array}{l}\text { this can be explained } \\
\text { by the fact that }\end{array}$ & $\begin{array}{l}\text { may be due to the pres- } \\
\text { ence of }\end{array}$ & $\begin{array}{l}\text { mechanism * is un- } \\
\text { known }\end{array}$ & $\begin{array}{l}\text { could be due to the fact } \\
\text { that the }\end{array}$ \\
\hline \multicolumn{4}{|c|}{ CF: Suggestion of future work } \\
\hline in the future we plan to & $\begin{array}{l}\text { studies } * \text { are in } \\
\text { progress }\end{array}$ & $\begin{array}{l}\text { this study has several } \\
\text { limitations }\end{array}$ & $\begin{array}{l}\text { it would be interesting } \\
\text { to compare }\end{array}$ \\
\hline $\begin{array}{l}\text { in the future we would } \\
\text { like to }\end{array}$ & $\begin{array}{l}\text { are currently underway } \\
\text { in our laboratory }\end{array}$ & $\begin{array}{l}\text { our study has several } \\
\text { limitations }\end{array}$ & $\begin{array}{l}\text { further research is } \\
\text { needed to clarify }\end{array}$ \\
\hline
\end{tabular}




\begin{tabular}{|c|c|c|c|}
\hline CL & Chem & Onc & Psy \\
\hline $\begin{array}{l}\text { in future work we plan } \\
\text { to } \\
\text { in future work we } \\
\text { would like to } \\
\text { as future work we plan } \\
\text { to }\end{array}$ & $\begin{array}{l}\text { studies * are currently } \\
\text { underway } \\
\text { are in progress in our } \\
\text { laboratory } \\
\text { are in progress and } \\
\text { will be reported in due } \\
\text { course }\end{array}$ & $\begin{array}{l}\text { this study has some } \\
\text { limitations } \\
\text { our study has some lim- } \\
\text { itations } \\
\text { it remains to be deter- } \\
\text { mined whether }\end{array}$ & $\begin{array}{l}\text { further research is } \\
\text { needed to determine } \\
\text { beyond the scope of } \\
\text { this paper } \\
\text { it would be interesting } \\
\text { to examine whether }\end{array}$ \\
\hline \multicolumn{4}{|l|}{ CF: Unexpected outcome } \\
\hline $\begin{array}{l}\text { government is autho- } \\
\text { rized to reproduce and } \\
\text { distribute reprints for }\end{array}$ & & $\begin{array}{l}\text { therefore it is not sur- } \\
\text { prising that }\end{array}$ & this \\
\hline $\begin{array}{l}\text { this is not surprising } \\
\text { given that }\end{array}$ & & it is not surprising that & $\begin{array}{l}\text { however this was not } \\
\text { the case }\end{array}$ \\
\hline what are kinds of & & $\begin{array}{l}\text { unexpectedly we found } \\
\text { that }\end{array}$ & this was not observed \\
\hline $\begin{array}{l}\text { it ports easily to new } \\
\text { language pairs the }\end{array}$ & & $\begin{array}{l}\text { thus it is not surprising } \\
\text { that }\end{array}$ & $\begin{array}{l}\text { this was not the case } \\
\text { for }\end{array}$ \\
\hline $\begin{array}{l}\text { is slightly different } \\
\text { from } * \text { official one } \\
\text { because } * \text { this figure if }\end{array}$ & & $\begin{array}{l}\text { interestingly we ob- } \\
\text { served that }\end{array}$ & $\begin{array}{l}\text { this was not the case in } \\
\text { the present study }\end{array}$ \\
\hline
\end{tabular}

Table 15: Discipline-specific FEs. 